\title{
Chasing Nepenthes on Cape York, Queensland
}

GARY W. WILSON - A ustralian Tropical Herbarium and School of Marine and Tropical Biology

- J ames Cook U niversity•C airns, Q ueensland •A ustralia • gary.wilson@ my.jcu.edu.au

FANIE Venter - A ustralian Tropical Herbarium • J ames Cook University • Cairns, Queensland

-A ustralia

RobYN F. WILSON • School of E arth \& Environmental Science • James Cook U niversity • Cairns,

Q ueensland $\bullet$ A ustralia

DARREN CRAYN • A ustralian Tropical Herbarium • James Cook U niversity • Cairns, Queensland

-A ustralia

Keywords: field studies: Nepenthes mirabilis, Nepenthes tenax, Nepenthes rowaniae, CapeYork, A ustralia

Little is known of the distribution, status and systematics of Nepenthes in the A ustro-Papuan region and there is some confusion about the number of species present (Clarke \& K ruger 2006). A project currently being conducted by staff and students of the A ustralian Tropical Herbarium and J ames Cook U niversity in Cairns, Q ueensland and M onash U niversity, Sunway Campus, Kuala Lumpur, M alaysia, is seeking to redress the situation. The study area extends from northern Queensland across the lowlands of the Trans-Fly Ecoregion in Papua N ew Guinea and West Papua, Indonesia, in the area south of Young's Line. This line delineates the northern margin of the A ustralia plate and the area is often contiguous when sea levels are lower, most recently c. 8000 years B P (see Figure 1).

This is a report on a recent field trip by PhD candidate Gary Wilson and staff Fanie Venter and Robyn Wilson to Cape York to familiarize themselves with the taxa and habitat of Nepenthes there,

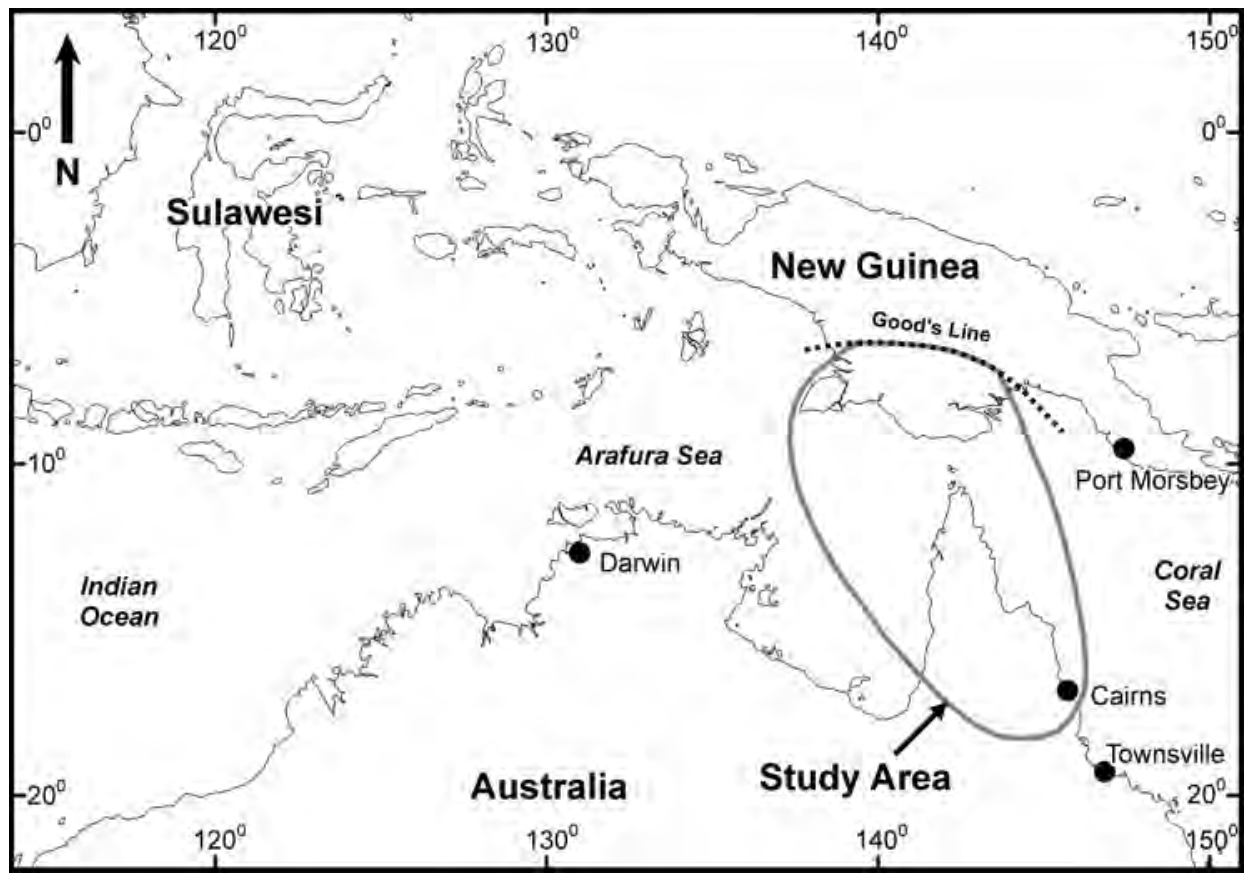

Figure 1: The study area. 

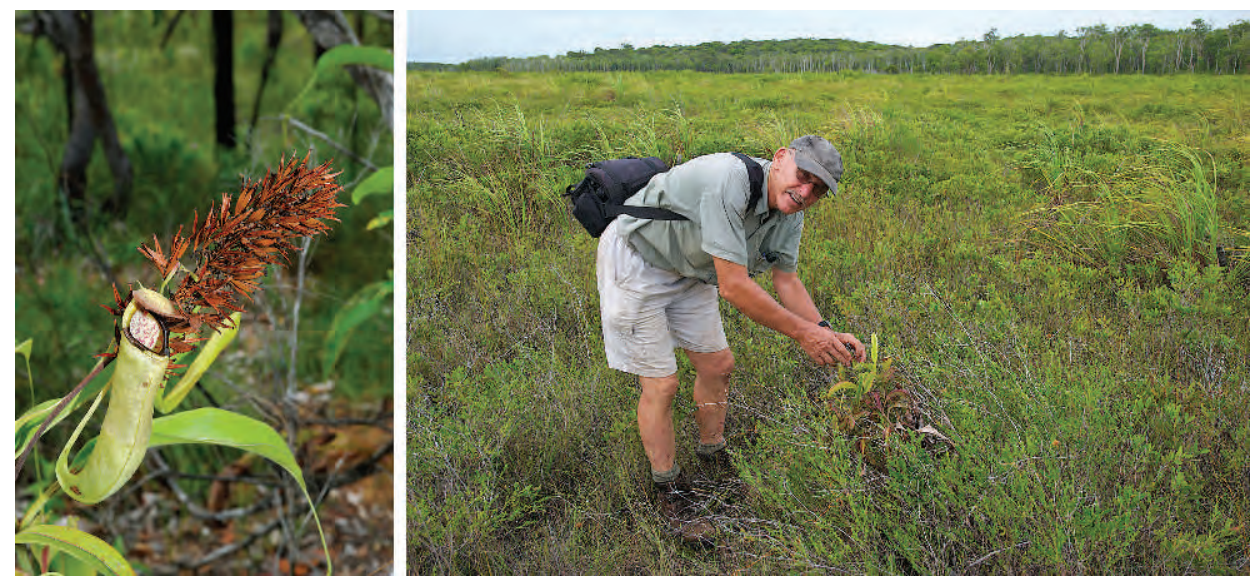

Figure 2: Nepenthes mirabilis and expended female fruit at Sheldon Lagoon (left); Fanie Venter with Nepenthes mirabilis in wetland habitat (right).

collect herbarium specimens and material for DNA sequence analysis, and choose locations for ecological studies to be conducted in the 2011 D ry Season when temperatures and rainfall are lower and study sites more easily accessible. The Cape constitutes the CapeYork bioregion of $127,175 \mathrm{~km}^{2}$, an area slightly less than that of England. It is renown for its diverse flora and fauna, some of which is shared with New Guinea, and is a mecca for A ustralian and overseas visitors alike. Fieldwork on the Cape is always a challenge; the single access road is unseal ed and often impassable during the Wet Season, c. mid-N ovember through A pril. A four-wheel drive vehicle is a necessity, temperatures can be high, and the presence of estuarine crocodile, Crocodylus porosus, makes caution about swamps and at river-crossings a must.

We undertook the trip in October and early November 2010, heading north at the end of the Dry Season when water levels in swamps are lowest and most visitors are heading south to escape the impending Wet. Given the time of the year and a forecast for a heavy Wet Season the strategy adopted was to head for TheTip and work south. W hile N. mirabilis occurs in a small area south of Cairns in the Wet Tropics bioregion, Nepenthes on the Cape are of interest because three species, N. mirabilis, N. tenax, and $\mathrm{N}$. rowaniae, occur there, often growing in distinct habitats but close proximity, and frequently hybridizing. In addition, several populations of Nepenthes of uncertain taxonomic status occur (see Clarke \& K ruger 2005, 2006; B easl ey 2009) and these warrant further investigation.

A ustralian state and national herbaria records show $\mathrm{N}$. mirabilis has been collected widely in a number of habitats across the Cape. However, they also show N. tenax and N. rowaniae have not often been collected and are restricted to swamps and their margins north of the Jardine River in the northern most part of the Cape. We encountered the first substantial populations of $\mathrm{N}$. mirabilis at Cockatoo Creek and nearby Sheldon Lagoon in the deep leached sands of $\mathrm{H}$ eathlands National Park; while we were familiar with the species from near Cairns, there was a palpable sense of excitement in seeing them in this habitat so far from home. M any plants were in flower and samples were collected and a photographic record was made (see Figure 2). From here we skirted northwards and found N. mirabilis in every area of suitable habitat, but the other species remained elusive until we crossed the J ardine River. We then skirted the southern margins of the J ardine and Sanamere Swamps that flood an area of $>400 \mathrm{~km}^{2}$ on a seasonal basis and are full of crocodiles. 

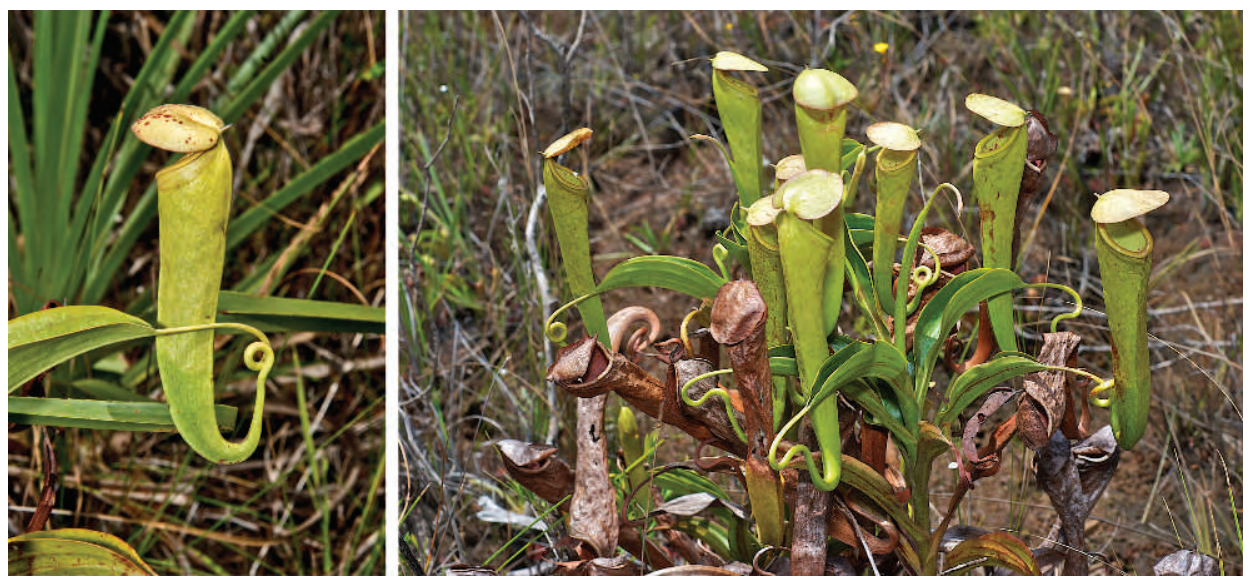

Figure 3: Nepenthes tenax.
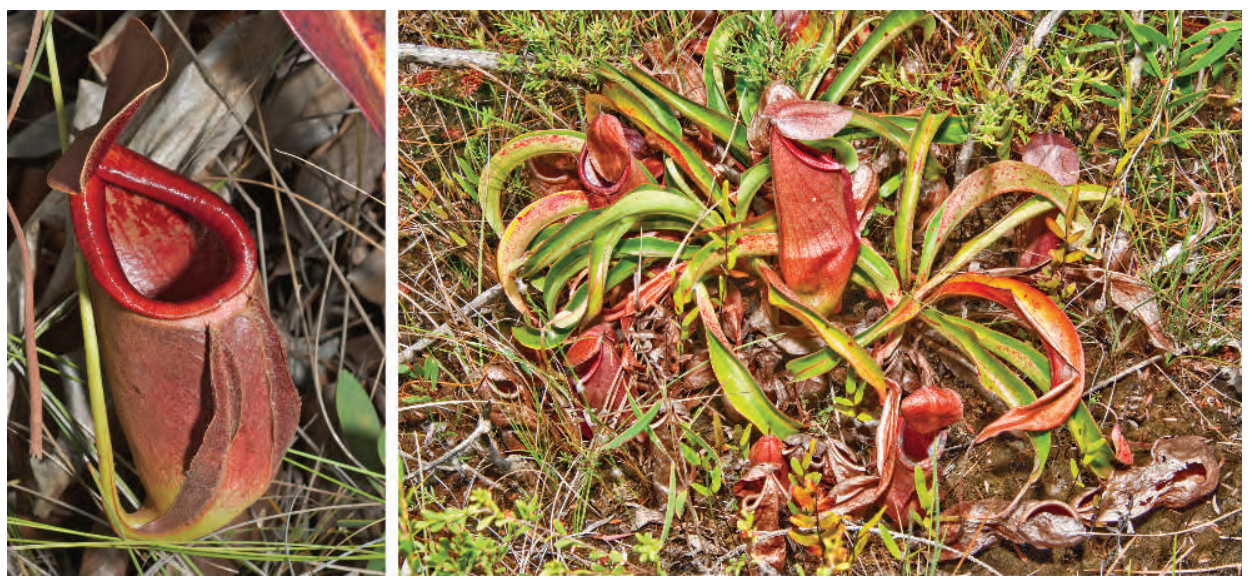

Figure 4: Nepenthes rowaniae in wetland habitat.

We continued on north to B amaga and touched base with A QIS (A ustralian Quarantine Inspection Service) staff, part of a team responsible for the health of flora and fauna in the northern Cape and adjacent Torres Strait, for a briefing on local conditions. Then it was through the L ockerbie Scrub to the site of the colonial settlement of Somerset, type location of N. rowaniae. We were not successful in finding this species here, probably due to our unfamiliarity with its habitat requirements. However, we found huge numbers of the toxic $\mathrm{C}$ ane Toad, B ufo marinus, whose introduction to A ustralia has caused the diminution of so many native species of fauna; at one site they were so noisy through the night we thought we had stumbled on a Harley-Davidson convention. We were also concerned about the numbers and activities of feral pigs, Sus scrofa, which are ripping up extensive areas of Nepenthes habitat. However, N. mirabilis was common and we surveyed and sampled populations in open freshwater wetland and closed riverine forest habitats. M orphological, morphometric, ecological, and AFLP (amplified fragment length polymorphism) DNA data from these populations will later be compared with those from the Wet Tropics and New Guinea. 


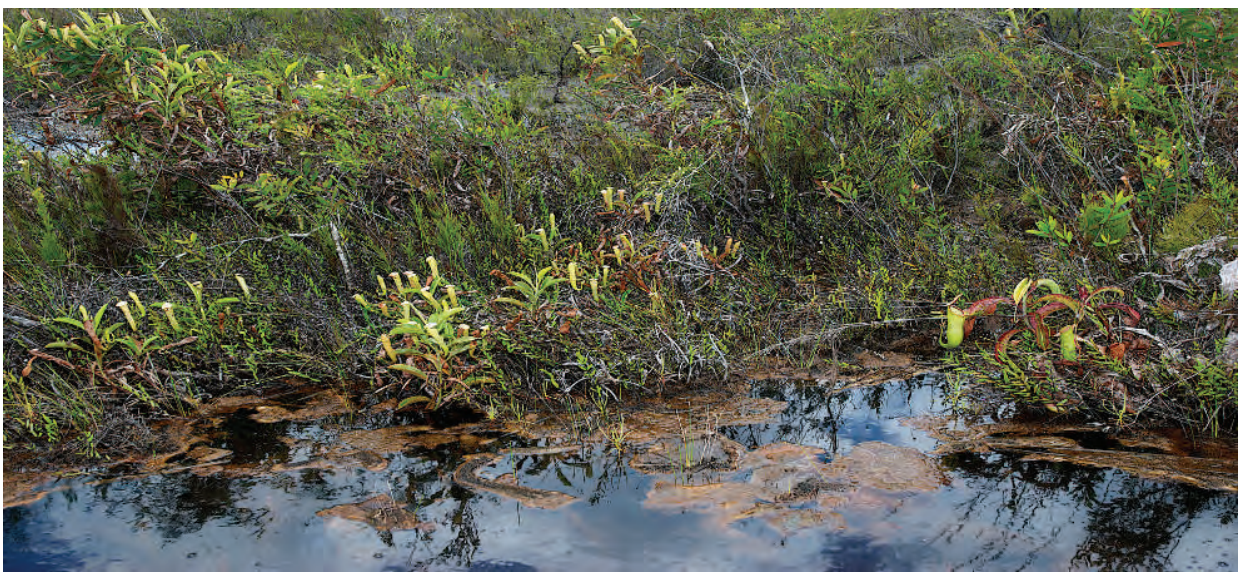

Figure 5: Nepenthes tenax (left) and N. mirabilis (right) in Sanamere Swamp.

We next headed to Sadd Point, in the far northeast of the Cape, to collect N epenthes there. Previous collections from this location had been identified as N. mi rabilis, but local botanist J ohn B easl ey had commented (Beasley 2010) that the morphology in some plants varied from those of typical N. mirabilis. B easley observed that leaves of some plants retained finely hairy margins and upper pitchers with characteristics such as wings with finely serrate margins, otherwise typical of lower pitchers, through to maturity. We made several collections, including one showing a development sequence from the form commented on by B easley through mature upper pitchers with morphology of typical N. mirabilis. While analysis of DNA sequence data will confirm or otherwise this, at the moment we are happy to assign all of the material to this species.

B ack on the main track and just east of the ferry crossing on the J ardine River we finally encountered both N. tenax and N. rowaniae (see Figures 3 and 4) at the head of Cowal Creek in the Sanamere Swamp. The habitat here is peat over sand with a mixed vegetation of sedges and low shrubs, and is cut by numerous channels flowing away to creeks and rivers in the north and west. Huge numbers of Nepenthes are present and it is an exciting and awe-inspiring sight. Nepenthes mirabilis is most com-
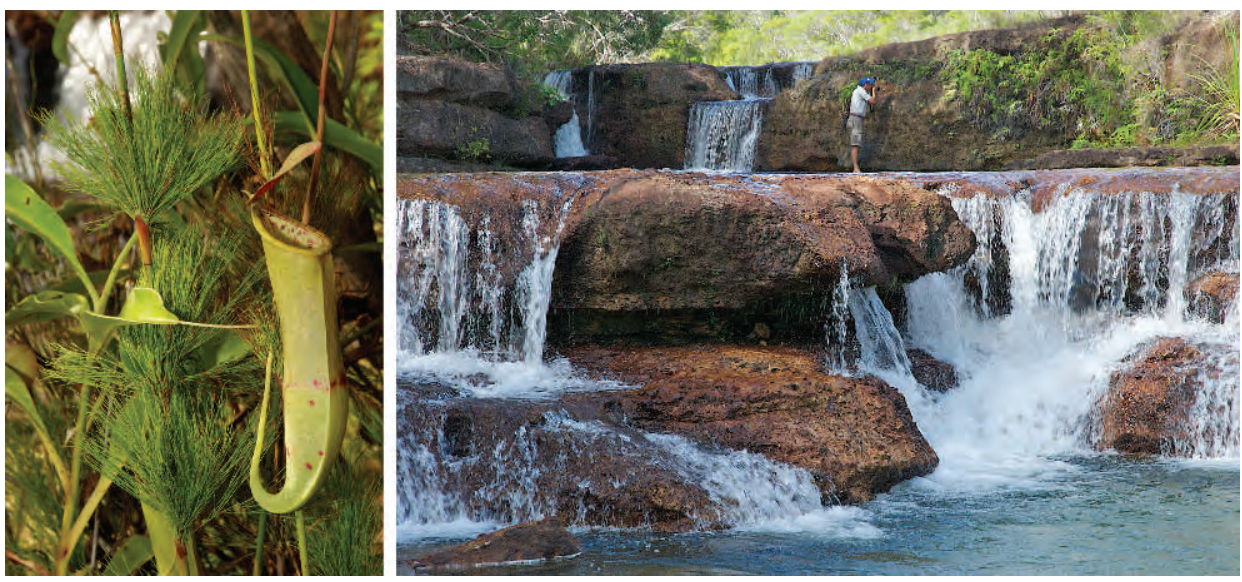

Figure 6: Nepenthes mirabilis at Twin Falls. 
mon in slightly drier areas and $\mathrm{N}$. tenax and $\mathrm{N}$. rowaniae in wetter areas. While the former often has a scrambling habit and tends to climb into higher vegetation, the other two form discrete clumps and sub-shrubs. In some areas N. tenax and N. mirabilis co-occurred and in these situations the differences in the two species were quite apparent (see Figure 5). A t this location, plants of each species would be submerged in water in the Wet Season and frequently subjected to wildfires during the Dry Season.

Studying N. tenax and N. rowaniae is challenging due to the difficulty in moving about in this habitat. In addition, the shade temperatures were 38 and $39^{\circ} \mathrm{C}$ on successive days. The sky was clear and so bright that reviewing digital images in the camera was almost impossible. The situation is further complicated as the species hybridize and we believe that several as yet undescribed entities also occur there. One of them, colloquially known as "mini-tenax", occurs deep in the swamps and is difficult to study, as crocodiles are common in the waist deep wa-

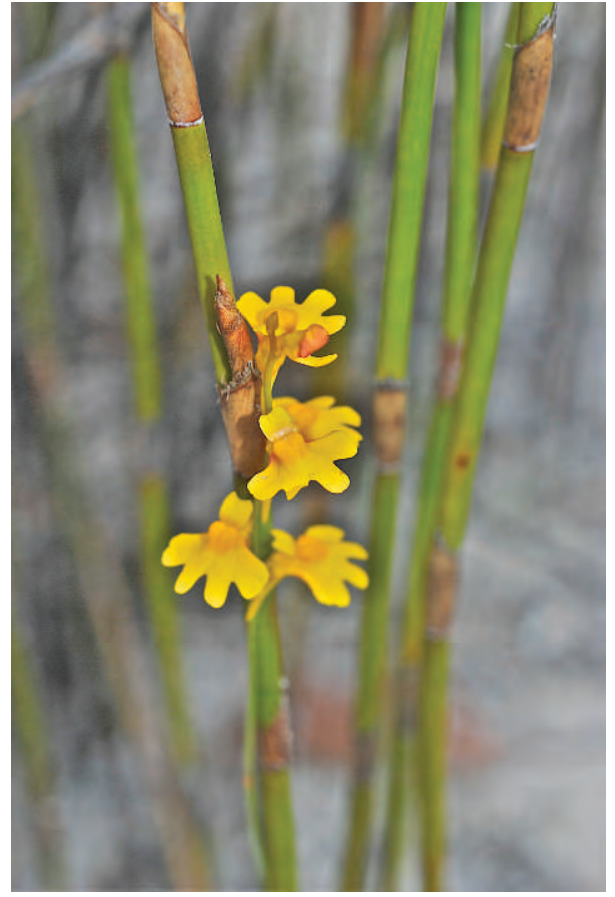

Figure 7: Utricularia chrysantha. ter of their habitat.

We continued our way south, stopping to photograph N. mirabilis on sandstones on the edge of the water at Twin Falls (see Figure 6) and to have a much-needed swim (it is one of the few places

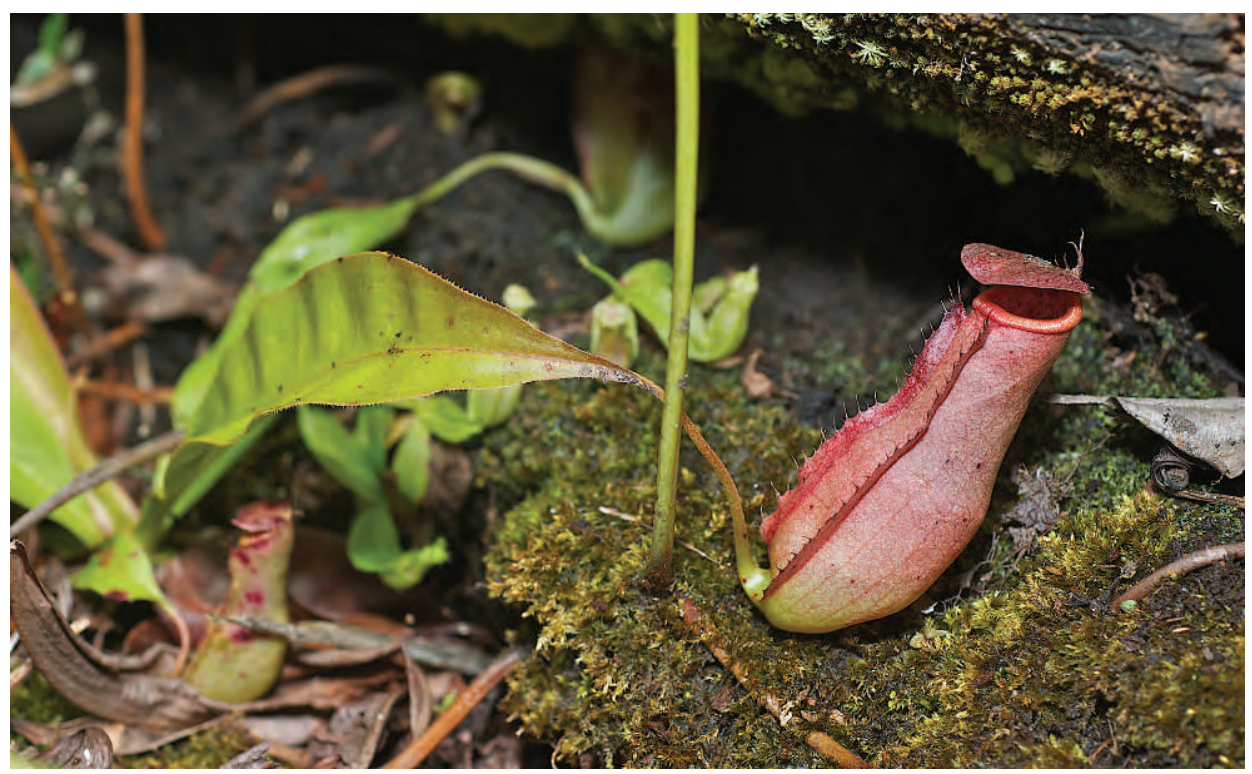

Figure 8: Nepenthes sp. juvenile lower pitcher at Steve Irwin Reserve. 

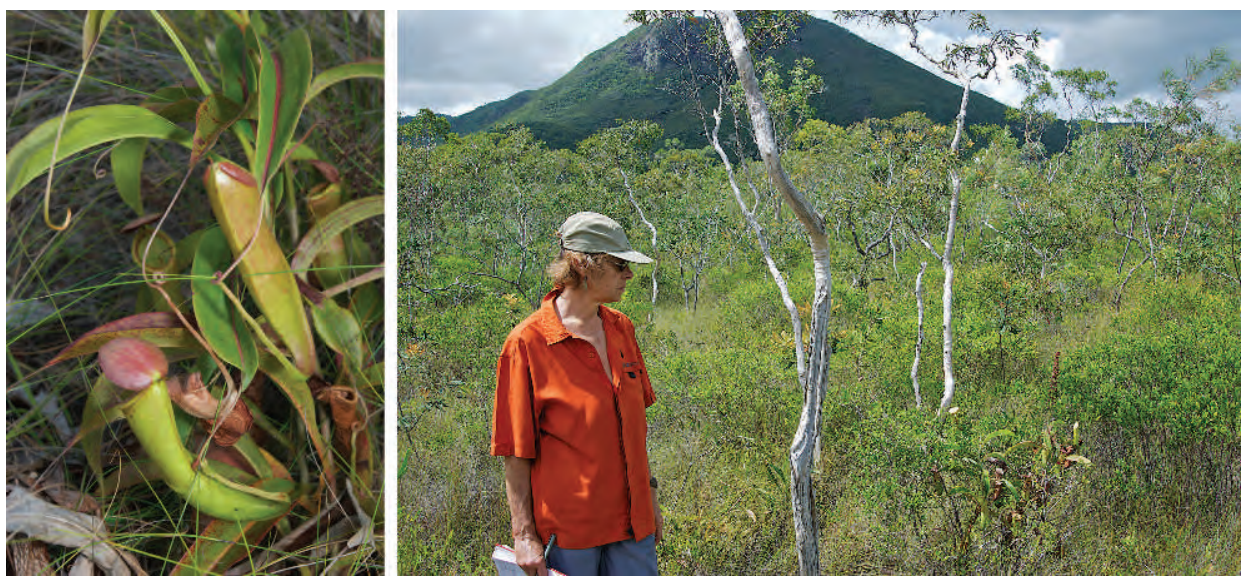

Figure 9: Nepenthes mirabilis (upper pitcher) and Robyn Wilson with Nepenthes mirabilis in habitat at Tozer Gap.

on CapeYork where it is safe to do so). Plants of N. mirabilis grew here in a narrow ecotone between water's edge and dry surrounding forest and some pitchers were held emergent from stems growing in the water. A few kilometers further south and a little further upstream at Fruit-bat Falls, in addition to N. mirabilis we photographed the carnivorous Sun B ladderwort, U tricularia chrysantha (see Figure 7) and the small, but exquisite, Straggly Rush Orchid, Conostalix paludicola (=D endrobium lobbii).

N orth of Weipa, the largest town on CapeYork and service centre for a local large alumina mine, we visited the Steve Irwin Research Reserve on the Wenlock River to study and sample Nepenthes growing in a spring at the base of a low bauxite plateau. Both N. mirabilis and what had been identified as $\mathrm{N}$. tenax had previously been collected from the site and we were keen to ascertain the veracity of the latter, as by this time our experience further north suggested it was unlikely $\mathrm{N}$. tenax would be present. The substrate at the spring was peaty sand and alluvium and supported a floristically distinct rain forest community that was in excellent condition due to the control of feral pigs by the resident ranger staff. We recollected both taxa and are of the opinion we are seeing variation in N. mirabilis - the second taxon (see Figure 8) has some differences in the developmental sequence of lower pitchers and additional study and the results of sequence data analysis will provide

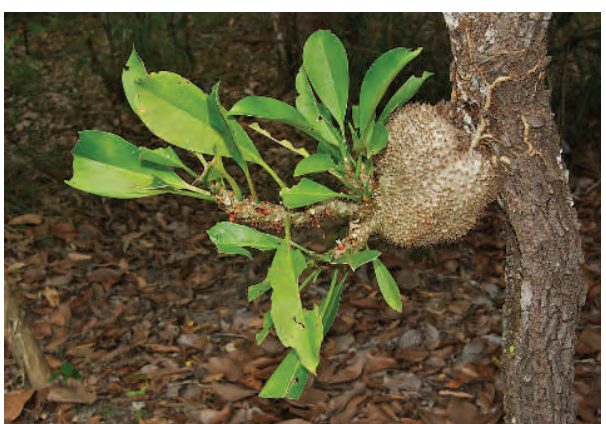

Figure 10: Myrmecodia beccarii at Tozer Gap. a definitive answer - certainly it is not $\mathrm{N}$. tenax sensu stricto.

We worked our way south and our final destination was Tozer Gap in the Iron Range National Park on the east coast of the Cape. Here N. mirabilis grows on leached sand in an el evated heathland (see Figure 9). I ron R ange is a mecca for both botanists and ornithologists, with a suite of species otherwise only found in N ew Guinea present here in the largest area of Iowland rain forest in A ustralia, so we stopped work for a day and took in the sights. Several species of epiphytic ant plants (Myrmecodia 
and $\mathrm{H}$ ydnophytum) were present and, although not carnivorous, were of interest because colonies of ants and sometimes the larvae of Theclinesthes butterflies live in them. These ant plants are in the Rubiaceae and we were delighted to find several plants of M yrmecodia beccarii in flower and fruit (see Figure 10), the small aromatic white flowers and red-coloured fleshy berries being remarkably similar to those of C offea (coffee), also in the Rubiaceae.

Back in Cairns and with the specimens in the drier, tissue samples collected to silica gel archived for later analysis, and images and morphometrics datasets backed up on the hard drive, we had time to consider what we had accomplished. In three weeks we had travelled 3000 kilometers, dodged the descending Wet, surveyed and sampled populations of three species across a range of habitats, re-sampled a population of dubious taxonomic status, and substantially expanded our knowledge of the ecology of Nepenthes in CapeYork.

Our initial impressions are that N. mirabilis is morphologically variable and occupies a broader ecological niche and occupies a much wider area than the other two named taxa; that accessing additional populations and conducting ecological studies of $\mathrm{N}$. rowaniae and $\mathrm{N}$. tenax is going to be challenging, and that more work is required to determine the status of the undetermined taxa. Only after this work is completed will we extend our activities to similar habitats across Torres Strait on the island of N ew Guinea.

A cknowledgements: Collections on this trip were made under Department of Environment and Resource M anagement (DERM) Permit \#WISP05396710. We thank AQIS staff Eric Cottis and J ames B ond in Bamaga, Senior Rangers at Heathlands NP, Iron Range NP, and Lakefield NP, Bernard Charlie of the Injinoo Council, Barry and Shelley Lyon at the Steve Irwin Scientific Reserve, and J ohn B easl ey of Kuranda for their guidance and assistance in our activities.

\section{References}

B easley, J. 2009. Plants of Cape York: the compact guide. K uranda, QId., A ustralia, J ohn B easl ey. Clarke, C.M ., and K ruger, R. 2005. N epenthes rowanae (N epenthaceae), a remarkable species from Cape York, A ustralia. Carniv. PI. N ewsl. 34(2): 36-41.

Clarke, C.M ., and K ruger, R. 2006. N epenthes tenax C.Clarke \& R.K ruger (Nepenthaceae), a new species from Cape York Peninsula, Queensland. A ustrobaileya 7(2): 319-324.

\section{Ferocious Foliage.com Custom Tissue Culture Laboratory}

* In vitro propagation of plants from material you provide

* Cloning and mass production

* Induced polyploidy, gibberellic acid and smoke water treatment

* Custom rooting of Nepenthes (your plants or our stock)

Why would you want these services?

* For very difficult species, have a lot of individuals to experiment with

* Propagate unique clones to share or sell

* Decrease risk of germination failure, especially if you have few seeds 